\title{
Effect of restricted feeding on the growth and body composition of European seabass Dicentrarchus labrax (Linnaeus, 1758)
}

\author{
BIROL BAKI, DILARA KAYA OZTURK, MERVE SARIIPEK, MURAT KERIM AND \\ BORA EYUBOGLU \\ Sinop University, Faculty of Fisheries, Aquaculture Department, Akliman-Sinop - 57000, Turkey \\ e-mail: bbaki@sinop.edu.tr
}

\begin{abstract}
The aim of this study was to determine the effects of restricted feeding on the growth and body composition in juvenile European seabass Dicentrarchus labrax, (Linnaeus, 1758). Four different feeding regimes were tested in fishes having average weight of $6.57 \pm 0.09 \mathrm{~g}$. The three treatment groups were fed three times a day adopting three different regimes: 6 days feeding/ 1 day starvation $(6 \mathrm{~F} / 1 \mathrm{~S}), 5$ days feeding/2 days starvation $(5 \mathrm{~F} / 2 \mathrm{~S})$ and 4 days feeding/3 days starvation $(4 \mathrm{~F} / 3 \mathrm{~S})$ for a period of 60 days. Control group $(\mathrm{C})$ was fed daily three times a day. At the end of the study the average weights were $31.21 \pm 1.39 \mathrm{~g}(\mathrm{C}), 36.47 \pm 1.33 \mathrm{~g}(6 \mathrm{~F} / 1 \mathrm{~S}), 29.01 \pm 1.01 \mathrm{~g}(5 \mathrm{~F} / 2 \mathrm{~S})$ and $24.21 \pm 0.82 \mathrm{~g}(4 \mathrm{~F} / 3 \mathrm{~S})$ respectively $(\mathrm{p}<0.05)$. SGR were $2.54 \pm 0.17(\mathrm{C}), 2.64 \pm 0.20(6 \mathrm{~F} / 1 \mathrm{~S}), 2.37 \pm 0.06(5 \mathrm{~F} / 2 \mathrm{~S})$ and $2.10 \pm 0.09(4 \mathrm{~F} / 3 \mathrm{~S})(\mathrm{p}<0.05)$ and $\mathrm{FCR}$ values recorded were $1.29 \pm 0.05(\mathrm{C}), 1.12 \pm 0.01(6 \mathrm{~F} / 1 \mathrm{~S}), 1.21 \pm 0.01(5 \mathrm{~F} / 2 \mathrm{~S})$ and $1.24 \pm 0.01(4 \mathrm{~F} / 3 \mathrm{~S})$. Crude protein and lipid values in restricted feeding groups were higher than those of the control group $(\mathrm{p}<0.05)$ while SFA and MUFA values increased with starvation period while DHA, EPA, PUFA and Omega-3 values decreased with starvation period $(p<0.05)$. Results of the study clearly showed that restricted feeding had effect on the growth parameters, biochemical composition and fatty acid compositions in European seabass.
\end{abstract}

Keywords: Biochemical composition, Dicentrarchus labrax, European seabass, Fatty acid composition, Growth performance, Restricted feeding

\section{Introduction}

Growth and metabolic response to starvation and refeeding in various species were studied by several workers (Perez-Jimenez et al., 2007; Eroldogan et al., 2008). In their natural environment, fish are exposed to feed deprivation during certain periods (McCue, 2010). Fish farms adopt modifications in aquaculture practices as well as in feeding strategies and expose farmed fish to short or long term starvation periods during certain times of the year for obtaining better growth and feed conversion ratios. Fish can exhibit different adaptation strategies during starvation periods (Takagi, 2001; Guderley et al., 2003). These adaptations vary with environmental conditions, fish species, starvation period and refeeding protocols (De Silva et al., 1997; Jobling and Johansen, 1999; Simkins, 2002; Perez-Jimenez et al., 2007; Peres et al., 2011). Studies have shown that, following starvation period, feed intake and growth increased very rapidly in European seabass with the renormalisation of the living environment or start of refeeding (Pastoureaud, 1991; Perez-Jimenez et al., 2007; Comoglio et al., 2008). Seabass can withstand long-term starvation conditions, however water temperature plays an important role. Starvation affects metabolic activities and stored energy reserves are used during this period which may result in weight loss.

The aim of the present study was to determine the effect of restricted feeding on the growth performance as well as on the biochemical and fatty acid compositions in juvenile seabass.

\section{Materials and methods}

The study was conducted at Sinop University Faculty of Fisheries, Aquatic Research Building (Sinop, Turkey). Fish having initial average weight of $6.57 \pm 0.09 \mathrm{~g}$ were used and four different feeding regimes were adopted for a period 60 days. The three treatment groups were fed three times a day: 6 days feeding/ 1 day starvation $(6 \mathrm{~F} / 1 \mathrm{~S})$, 5 days feeding/2 days starvation $(5 \mathrm{~F} / 2 \mathrm{~S})$ and 4 days feeding/3 days starvation $(4 \mathrm{~F} / 3 \mathrm{~S})$ respectively. Control group (C) was fed three times daily. The fish were fed with commercial feed having 48:16 protein/fat ratio. Twelve 1001 fiberglass tanks were used with 3 replications for each treatment.

Temperature, oxygen, $\mathrm{pH}$ and salinity of the rearing water were measured twice a day before feeding throughout the study using WTW multi-parameter device. The 
average water temperature, oxygen level, $\mathrm{pH}$ and salinity values recorded were: $25.61 \pm 0.01^{\circ} \mathrm{C}, 6.41 \pm 0.13 \mathrm{mg} \mathrm{l}^{-1}$, $7.21 \pm 0.06$ and $18.30 \pm 0.01$ ppt respectively.

During the experimental period, fishes were sampled from each group and growth parameters of the fish and biochemical compositions of fish meat were determined. Biometric data of the fish were collected and growth performance, viserosomatic index (VSI), hepatosomatix index (HSI), carcass yield (CY) and condition factor (CF) values were calculated (Skalli and Rabin, 2004; Hossu et al., 2005; Cui et al., 2006) using the following formulae:

Specific growth rate $(\mathrm{SGR})(\%)=\frac{\operatorname{Ln} \text { Final weight }(\mathrm{g})-\text { Ln Initial weight }(\mathrm{g})}{\text { Day }} \times 100$

Specific feed rate $=\mathrm{SGR} * \mathrm{FCR}$

Feed conversion ratio $(\mathrm{FCR})=\frac{\text { Total amount of feed consumed }(\mathrm{g})}{\text { Total weight gain }(\mathrm{g})}$

DFC (Average daily feed consumption $)=$ Feed consumption/ days

Protein efficiency rate $(\mathrm{PER})(\%)=\frac{\text { Live weight gains }(\mathrm{g})}{\text { Protein intake }(\mathrm{g})} \times 100$

$\operatorname{HSI}(\%)=\frac{\text { Liver weight }(\mathrm{g})}{\text { Total body weight }(\mathrm{g})} \times 100$

VSI $(\%)=\frac{\text { Vicera weight }(\mathrm{g})}{\text { Total body weight }(\mathrm{g})} \times 100$

Carcass yield $(\mathrm{CY})(\%)=\frac{\text { Edible fillet weight }(\mathrm{g})}{\text { Total body weight }(\mathrm{g})} \times 100$

Condition factor $(\mathrm{CF})=\frac{\mathrm{W}}{\mathrm{L}^{3}} \times 100$
The fillet crude protein (\%), crude lipid (\%) and moisture (\%) analysis were carried out according to Weende method, acid hydrolysis in Soxtec System and by drying method respectively following Association of Official Analytical Chemists (AOAC, 2000). The fillets were stored at $-20^{\circ} \mathrm{C}$ until used for biochemical analyses. Fatty acid analysis was done by Gas chromatography (IUPAC, Firestone and Horwitz, 1979) at TUBITAK Marmara Research Center Food Institute. The fish were stored at $-80^{\circ} \mathrm{C}$ until analysis.

The data obtained were tested with one way ANOVA using SPSS 21 software. The differences between the average values were compared using Tukey's multiple comparison tests at $\mathrm{p}<0.05$ significance level.

\section{Results and discussion}

On termination of feeding, weight gain $(36.47 \pm 1.33 \mathrm{~g})$, specific growth rate $(2.64 \pm 0.20)$ and FCR values of $6 \mathrm{~F} / 1 \mathrm{~S}$ group were found better than those of other groups (Table 1, Fig. 1, 2). Starvation period was found to have an effect on weight gain and growth. The lowest weight gain and SGR values were recorded in $4 \mathrm{~F} / 3 \mathrm{~S}$ group while the lowest FCR value was detected in control group $(p<0.05)$. The differences between the groups in terms of PER values were not significant $(p>0.05)$, while the lowest $C Y$ and $\mathrm{CF}$ values were determined in $4 \mathrm{~F} / 3 \mathrm{~S}$ group $(\mathrm{p}<0.05)$. Wu et al. (2004) reported that growth performance and feed consumption values in 1-day starvation group and continuous feeding groups were similar while Turkmen et al. (2011) reported slowest growth in groups subjected to restricted feeding. Hu et al. (2001) observed a more rapid growth during feeding following the starvation

Table 1. Growth performance, whole body and fillet proximate composition of European seabass on termination of experimental feeding

\begin{tabular}{|c|c|c|c|c|}
\hline \multicolumn{5}{|c|}{ Treatment group } \\
\hline Growth parameters & Control & $6 \mathrm{~F} / 1 \mathrm{~S}$ & $5 \mathrm{~F} / 2 \mathrm{~S}$ & $4 \mathrm{~F} / 3 \mathrm{~S}$ \\
\hline Initial weight (g) & $6.57 \pm 0.08$ & $6.57 \pm 0.08$ & $6.58 \pm 0.01$ & $6.57 \pm 0.02$ \\
\hline Final weight (g) & $31.21 \pm 1.39^{\mathrm{b}}$ & $36.47 \pm 1.33^{c}$ & $29.01 \pm 1.01^{\mathrm{b}}$ & $24.21 \pm 0.82^{\mathrm{a}}$ \\
\hline SGR $(\%)$ & $2.54 \pm 0.17^{\mathrm{c}}$ & $2.64 \pm 0.20^{c}$ & $2.37 \pm 0.06^{\mathrm{b}}$ & $2.10 \pm 0.09^{\mathrm{a}}$ \\
\hline FCR & $1.29 \pm 0.05^{\mathrm{b}}$ & $1.12 \pm 0.01^{\mathrm{a}}$ & $1.21 \pm 0.01^{\mathrm{b}}$ & $1.24 \pm 0.01^{\mathrm{b}}$ \\
\hline DFC & $6.78 \pm 0.16$ & $7.13 \pm 0.23$ & $8.02 \pm 0.35$ & $8.03 \pm 0.59$ \\
\hline PER & $2.86 \pm 0.08^{\mathrm{a}}$ & $2.86 \pm 0.01^{\mathrm{a}}$ & $2.96 \pm 0.01^{\mathrm{a}}$ & $2.89 \pm 0.03^{\mathrm{a}}$ \\
\hline HSI & $2.31 \pm 0.20^{\mathrm{b}}$ & $2.58 \pm 0.12^{\mathrm{b}}$ & $2.07 \pm 0.18^{\mathrm{ab}}$ & $1.70 \pm 0.12^{\mathrm{a}}$ \\
\hline VSI & $7.56 \pm 0.40^{\mathrm{a}}$ & $8.36 \pm 0.57^{\mathrm{a}}$ & $8.65 \pm 045^{\mathrm{a}}$ & $8.79 \pm 0.33^{\mathrm{a}}$ \\
\hline $\mathrm{CY}$ & $41.49 \pm 0.41^{b}$ & $40.82 \pm 0.51^{\mathrm{ab}}$ & $38.97 \pm 0.30^{\mathrm{ab}}$ & $38.35 \pm 0.56^{\mathrm{a}}$ \\
\hline $\mathrm{CF}$ & $1.23 \pm 0.02^{\mathrm{b}}$ & $1.28 \pm 0.02^{\mathrm{b}}$ & $1.17 \pm 0.02^{\mathrm{ab}}$ & $1.13 \pm 0.02^{\mathrm{a}}$ \\
\hline \multicolumn{5}{|c|}{ Proximate composition (Fillet)* } \\
\hline Protein & $19.29 \pm 0.38^{\mathrm{a}}$ & $20.32 \pm 0.08^{\mathrm{ab}}$ & $20.17 \pm 0.16^{\mathrm{ab}}$ & $20.71 \pm 0.07^{\mathrm{b}}$ \\
\hline Lipid & $2.73 \pm 0.30^{\mathrm{a}}$ & $2.80 \pm 0.15^{\mathrm{a}}$ & $4.15 \pm 0.17^{\mathrm{b}}$ & $4.03 \pm 0.09^{\mathrm{b}}$ \\
\hline Dry mater & $24.29 \pm 0.05^{\mathrm{a}}$ & $24.51 \pm 0.14^{\mathrm{a}}$ & $24.64 \pm 0.02^{\mathrm{a}}$ & $24.24 \pm 0.02^{\mathrm{a}}$ \\
\hline Ash & $1.44 \pm 0.02^{\mathrm{a}}$ & $1.24 \pm 0.04^{\mathrm{a}}$ & $1.36 \pm 0.03^{\mathrm{a}}$ & $1.35 \pm 0.02^{\mathrm{a}}$ \\
\hline
\end{tabular}

Values in the same row with different superscripts are significantly different $(\mathrm{p}<0.05)$.

*Biochemical analysis were performed on wet weight basis 


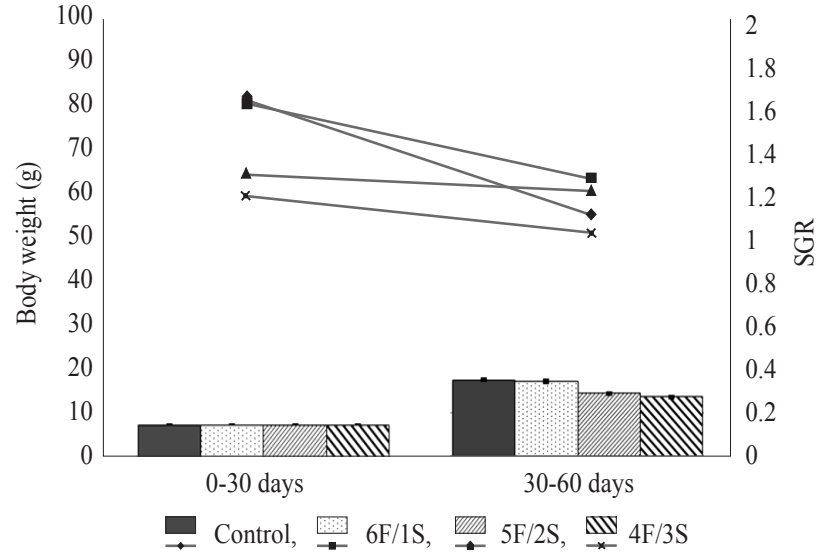

Fig. 1. Weight gain values and specific growth rates in European seabass during the experimental period

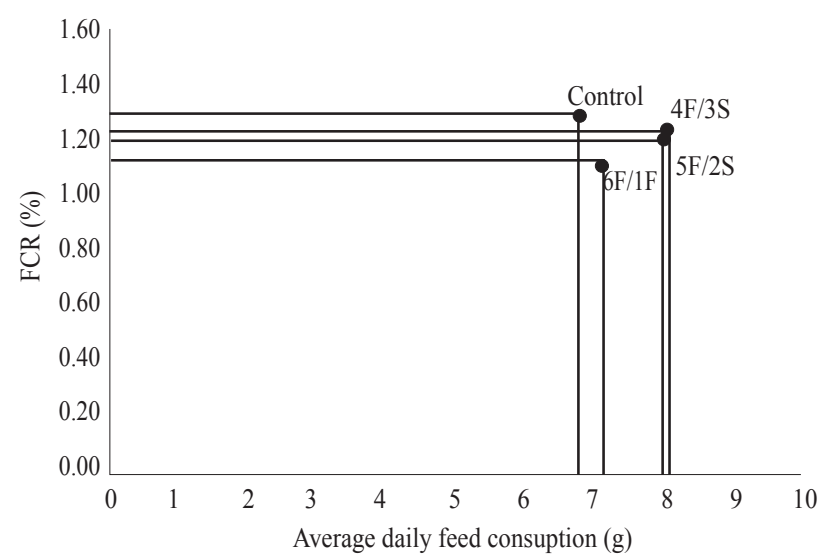

Fig. 2. Daily average feed consumptions and feed conversion ratios in European seabass during the experimental period

period. Studies have also reported reduction in the SGR during starvation period (Eroldogan et al., 2006; Jobling, 2010).

In the present study, the highest feed consumption was recorded in $4 \mathrm{~F} / 3 \mathrm{~S}$ group $(8.03 \pm 0.59 \mathrm{~g})$ while the lowest value was observed in the control group $(6.78 \pm 0.16 \mathrm{~g})$. Better FCR value were obtained in limited feeding groups compared to those of the control group and the highest value was found in $6 \mathrm{~F} / 1 \mathrm{~S}$ group $(1.12 \pm 0.01)$. It has been reported that limited feeding methods increased the amount of feed given daily and decreased FCR (Wang et al., 2000; Eroldogan et al., 2006; Adaklı and Tasbozan, 2015).

VSI values of limited feeding groups were higher than that of the control group whereas HSI values were lower than that of the control group except in $6 \mathrm{~F} / 1 \mathrm{~S}$ group. A linear relationship was observed between starvation period and VSI value. McCue (2010) observed that with starvation weight loss started initially in the digestive system. Starvation may lead to decrease in HSI values
(Echevarria et al., 1997; Sevgili, 2007) and increase in VSI values (Eroldogan et al., 2006).

Protein, fat, dry matter and ash values recorded at the beginning of the study were: $17.97 \pm 0.29,1.27 \pm 0.05$, $22.94 \pm 0.24$ and $1.52 \pm 0.06 \%$ respectively. On termination of the study, crude protein and crude fat values in limited feeding groups were found higher than those of control group $(\mathrm{p}<0.05)$, whereas there were no significant differences between the dry matter values $(p>0.05)$. It is a known fact that starvation leads to changes in biochemical composition of the body (Jobling, 2010). Some limited feeding studies have reported decreased protein and lipid values during restricted feeding (Peres et al., 2011; Adakli and Tasbozan, 2015; Gao et al., 2015; Halder and Ali, 2015), whereas some have reported decreased protein and increased lipid values (Simkins, 2002; Wu et al., 2004). It was found that, both low growth parameters and high lipid values especially in $5 \mathrm{~F} / 2 \mathrm{~S}$ and $4 \mathrm{~F} / 3 \mathrm{~S}$ groups which exhibited low growth rates indicate that a significant proportion of the protein sources taken via feed were used for energy needs during starvation periods. It was found that during limited feeding in juvenile fish which require high levels of protein and energy, significant proportion of the protein sources in feed were used for energy needs.

It was found that similar values were obtained for certain fatty acids (lauric acid, tridecanoic acid, pentadecanoic acid, arachidic acid, behenic acid, tricosanoic acid, lingoceric acid, myristoleic acid, eicosenoic acid, erucic acid, nervonic acid, linoleic acid, $\gamma$-linolenic acid, eicosadienoic acid, eicosatrienoic acid, cis-8.11.14-eicosatrienoic acid, arachidonic acid, docosadienoic acid) in limited feeding groups and control group. Palmitic acid, stearic acid, palmiteloic acid and oleic acid values were higher in limited feeding group, whereas heptadecanoic acid, $\alpha$-linolenic acid, eicosadienoic acid and docosapentaenoic acid values were higher in control group $(\mathrm{p}<0.05)$ (Table 2).

Myristic acid (C14: 0) $(5.26 \% \pm 0.03)$, palmitic acid (C16:0) (23:25\% \pm 0.05$)$, heptadecanoic acid (C17:0) $(0.59 \% \pm 0)$, stearic acid (C18:0) $(5.78 \% \pm 0)$ and docosapentaenoic acid (C22:5N3) $(0.89 \% \pm 0.01)$ values decreased in all groups at the end of the study. Differences between the control group and the limited feeding groups were significant $(\mathrm{p}<0.05)$. Palmitoleic acid $(\mathrm{C} 16: 1)$ $(4.97 \% \pm 0.02)$, oleic acid $(\mathrm{C} 18: 1 \mathrm{n} 9 \mathrm{c})(17: 56 \% \pm 0.01)$ and $\alpha$-linolenic acid $(\mathrm{C} 18: 3 \mathrm{n} 3)(0.94 \% \pm 0)$ values increased in all groups at the end of the study. The differences between the control group and the limited feeding groups were significant $(\mathrm{p}<0.05)$. $\sum$ SFA and $\sum$ MUFA values were higher in limited feeding groups compared to the 
Table 2. Fatty acid composition of fish meat (\%) in different experimental groups of European seabass

\begin{tabular}{|c|c|c|c|c|c|}
\hline \multirow{2}{*}{ Fatty acids } & \multirow{2}{*}{ Day 0} & \multicolumn{4}{|c|}{ Day 60} \\
\hline & & Control & $6 \mathrm{~F} / 1 \mathrm{~S}$ & $5 \mathrm{~F} / 2 \mathrm{~S}$ & $4 \mathrm{~F} / 3 \mathrm{~S}$ \\
\hline C12:0 Lauric acid & $0.07 \pm 0^{\mathrm{a}}$ & $0.05 \pm 0^{\mathrm{a}}$ & $0.05 \pm 0^{\mathrm{a}}$ & $0.05 \pm 0^{\mathrm{a}}$ & $0.05 \pm 0^{\mathrm{a}}$ \\
\hline C13:0 Tridecanoic acid & 0 & $0.04 \pm 0^{\mathrm{a}}$ & $0.04 \pm 0.01^{\mathrm{a}}$ & $0.03 \pm 0^{\mathrm{a}}$ & $0.04 \pm 0.01^{\mathrm{a}}$ \\
\hline C14:0 Myristic Acid & $5.26 \pm 0.03^{\mathrm{c}}$ & $4.46 \pm 0.01^{\mathrm{b}}$ & $4.31 \pm 0.01^{\mathrm{a}}$ & $4.31 \pm 0.01^{\mathrm{a}}$ & $4.26 \pm 0^{\mathrm{a}}$ \\
\hline C15:0 Pentadecanoic Acid & $0.69 \pm 0.01^{\mathrm{b}}$ & $0.72 \pm 0.01^{\mathrm{a}}$ & $0.68 \pm 0^{\mathrm{a}}$ & $0.70 \pm 0^{\mathrm{a}}$ & $0.70 \pm 0.01^{\mathrm{a}}$ \\
\hline C16:0 Palmitik Acid & $23.25 \pm 0.05^{\mathrm{c}}$ & $20.32 \pm 0.01^{\mathrm{a}}$ & $20.77 \pm 0.01^{\mathrm{b}}$ & $20.66 \pm 0.01^{\mathrm{b}}$ & $20.73 \pm 0^{\mathrm{b}}$ \\
\hline C17:0 Heptadecanoic Acid & $0.59 \pm 0^{\mathrm{b}}$ & $0.57 \pm 0^{\mathrm{c}}$ & $0.54 \pm 0^{\mathrm{a}}$ & $0.55 \pm 0^{\mathrm{a}}$ & $0.55 \pm 0.01^{\mathrm{a}}$ \\
\hline C18:0 Stearic Acid & $5.78 \pm 0^{\mathrm{e}}$ & $3.95 \pm 0^{\mathrm{a}}$ & $4.16 \pm 0^{\mathrm{b}}$ & $4.27 \pm 0.01^{\mathrm{d}}$ & $4.19 \pm 0.01^{\mathrm{c}}$ \\
\hline C20:0 Arachidic Acid & $0.48 \pm 0.01^{\mathrm{c}}$ & $0.39 \pm 0^{\mathrm{a}}$ & $0.38 \pm 0^{\mathrm{a}}$ & $0.41 \pm 0,01^{\mathrm{ab}}$ & $0.42 \pm 0^{\mathrm{b}}$ \\
\hline C22:0 Behenic Acid & $0.15 \pm 0.01^{\mathrm{c}}$ & $0.12 \pm 0^{\mathrm{a}}$ & $0.12 \pm 0^{\mathrm{a}}$ & $0.13 \pm 0^{\mathrm{ab}}$ & $0.14 \pm 0^{\mathrm{bc}}$ \\
\hline C23:0 Tricosanoic Acid & 0 & $0.04 \pm 0.01^{\mathrm{a}}$ & $0.03 \pm 0^{\mathrm{a}}$ & $0.04 \pm 0^{\mathrm{a}}$ & $0.04 \pm 0^{\mathrm{a}}$ \\
\hline C24:0 Lingoceric Acid & $0.14 \pm 0.01^{\mathrm{c}}$ & $0.09 \pm 0^{\mathrm{a}}$ & $0.09 \pm 0^{\mathrm{a}}$ & $0.10 \pm 0^{\mathrm{ab}}$ & $0.11 \pm 0^{\mathrm{b}}$ \\
\hline$\sum \mathrm{SFA}$ & $36.39 \pm 0.1^{\mathrm{c}}$ & $30.70 \pm 0.01^{\mathrm{a}}$ & $31.16 \pm 0.01^{\mathrm{b}}$ & $31.24 \pm 0.02^{\mathrm{b}}$ & $31.21 \pm 0.01^{\mathrm{b}}$ \\
\hline C14:1 Myristoleic Acid & $0.04 \pm 0^{\mathrm{a}}$ & $0.08 \pm 0.01^{\mathrm{b}}$ & $0.08 \pm 0^{\mathrm{b}}$ & $0.07 \pm 0^{\mathrm{b}}$ & $0.07 \pm 0^{\mathrm{b}}$ \\
\hline C16:1 Palmitoleic acid & $4.97 \pm 0.02^{\mathrm{a}}$ & $5.16 \pm 0^{\mathrm{b}}$ & $5.27 \pm 0^{\mathrm{c}}$ & $5.27 \pm 0.05^{\mathrm{c}}$ & $5.30 \pm 0^{\mathrm{c}}$ \\
\hline C18:1n9c Oleic Acid & $17.56 \pm 0.01^{\mathrm{a}}$ & $21.46 \pm 0.01^{\mathrm{b}}$ & $22.41 \pm 0.01^{\mathrm{e}}$ & $21.63 \pm 0.01^{\mathrm{c}}$ & $21.93 \pm 0^{\mathrm{d}}$ \\
\hline C20:1n9c Eicosenoikasit & $1.23 \pm 0.01^{\mathrm{d}}$ & $0.90 \pm 0^{\mathrm{ab}}$ & $0.88 \pm 0.01^{\mathrm{a}}$ & $0.91 \pm 0^{\mathrm{bc}}$ & $0.93 \pm 0.08^{c}$ \\
\hline C22:1n9 Erucic Acid & $0.21 \pm 0.01^{\mathrm{b}}$ & $0.14 \pm 0^{\mathrm{a}}$ & $0.14 \pm 0^{\mathrm{a}}$ & $0.15 \pm 0^{\mathrm{a}}$ & $0.16 \pm 0.01^{\mathrm{a}}$ \\
\hline C24:1 Nervonic acid & $0.49 \pm 0.01^{\mathrm{b}}$ & $0.46 \pm 0^{\mathrm{a}}$ & $0.45 \pm 0^{\mathrm{a}}$ & $0.50 \pm 0.01^{\mathrm{b}}$ & $0.54 \pm 0.01^{\mathrm{c}}$ \\
\hline$\sum$ MUFA & $24.48 \pm 0^{\mathrm{a}}$ & $28.20 \pm 0.01^{\mathrm{b}}$ & $29.22 \pm 0.01^{\mathrm{e}}$ & $28.52 \pm 0.01^{\mathrm{c}}$ & $28.92 \pm 0.01^{\mathrm{d}}$ \\
\hline C18:2n6c Linoleic Acid & $8.18 \pm 0.01^{\mathrm{c}}$ & $7.07 \pm 0.01^{\mathrm{b}}$ & $6.89 \pm 0.01^{\mathrm{a}}$ & $7.06 \pm 0^{\mathrm{b}}$ & $7.06 \pm 0.01^{\mathrm{b}}$ \\
\hline C18:3n6 $\gamma$-Linolenic Acid & $0.15 \pm 0.01^{\mathrm{a}}$ & $0.17 \pm 0^{\mathrm{b}}$ & $0.16 \pm 0^{\mathrm{ab}}$ & $0.17 \pm 0.01^{\mathrm{b}}$ & $0.17 \pm 0.01^{\mathrm{b}}$ \\
\hline C18:3n3 $\alpha$-Linolenic Acid & $0.94 \pm 0^{\mathrm{a}}$ & $1.22 \pm 0^{\mathrm{d}}$ & $1.17 \pm 0.01^{\mathrm{b}}$ & $1.20 \pm 0^{\mathrm{c}}$ & $1.16 \pm 0.01^{\mathrm{b}}$ \\
\hline C20:2 Eicosadienoik acid & $1.25 \pm 0.01^{\mathrm{a}}$ & $1.36 \pm 0^{\mathrm{c}}$ & $1.33 \pm 0^{\mathrm{b}}$ & $1.35 \pm 0^{\mathrm{c}}$ & $1.32 \pm 0^{\mathrm{b}}$ \\
\hline C20:3n3 EikosatrienoikAsit & $0.08 \pm 0^{\mathrm{a}}$ & $0.11 \pm 0^{\mathrm{a}}$ & $0.10 \pm 0^{\mathrm{a}}$ & $0.11 \pm 0^{\mathrm{a}}$ & $0.11 \pm 0^{\mathrm{a}}$ \\
\hline C20:3n6 cis-8.11.14-Eicosatrienoik asit & $0.09 \pm 0.01^{\mathrm{a}}$ & $0.09 \pm 0.01^{\mathrm{a}}$ & $0.08 \pm 0^{\mathrm{a}}$ & $0.09 \pm 0^{\mathrm{a}}$ & $0.09 \pm 0^{\mathrm{a}}$ \\
\hline $\mathrm{C} 20: 5 \mathrm{n} 3 \mathrm{EPA}$ & $5.19 \pm 0.01^{\mathrm{a}}$ & $6.01 \pm 0.01^{\mathrm{c}}$ & $5.98 \pm 0.01^{\mathrm{c}}$ & $6.01 \pm 0.01^{\mathrm{c}}$ & $5.88 \pm 0.01^{\mathrm{b}}$ \\
\hline C 20:4n6 Araşidonik acid & $0.83 \pm 0.02^{\mathrm{c}}$ & $0.57 \pm 0.01^{\mathrm{b}}$ & $0.54 \pm 0.01^{\mathrm{b}}$ & $0.57 \pm 0.01^{\mathrm{b}}$ & $0.48 \pm 0^{\mathrm{a}}$ \\
\hline C22: 6n3 DHA & $12.31 \pm 0.09^{\mathrm{a}}$ & $14.49 \pm 0.01^{\mathrm{c}}$ & $13.77 \pm 0.01^{\mathrm{b}}$ & $13.98 \pm 0.01^{\mathrm{b}}$ & $13.84 \pm 0.03^{\mathrm{b}}$ \\
\hline C22:5n3 Dokosapentanoik acid & $0.89 \pm 0.01^{\mathrm{d}}$ & $0.78 \pm 0^{\mathrm{c}}$ & $0.75 \pm 0^{\mathrm{ab}}$ & $0.77 \pm 0.01^{\mathrm{bc}}$ & $0.74 \pm 0.01^{\mathrm{a}}$ \\
\hline C22:2 Dokosadienoik acid & $0.27 \pm 0^{\mathrm{a}}$ & $0.35 \pm 0^{\mathrm{b}}$ & $0.34 \pm 0^{\mathrm{b}}$ & $0.35 \pm 0.01^{\mathrm{b}}$ & $0.34 \pm 0^{\mathrm{b}}$ \\
\hline$\sum$ PUFA & $30.16 \pm 0^{\mathrm{a}}$ & $32.20 \pm 0.01^{\mathrm{d}}$ & $31.09 \pm 0.01^{\mathrm{b}}$ & $31.63 \pm 0.03^{\mathrm{c}}$ & $31.16 \pm 0.01^{\mathrm{b}}$ \\
\hline Omega 3 & $19.41 \pm 0.09^{\mathrm{a}}$ & $22.60 \pm 0.01^{\mathrm{d}}$ & $21.76 \pm 0.01^{\mathrm{b}}$ & $22.06 \pm 0.02^{\mathrm{c}}$ & $21.71 \pm 0.01^{\mathrm{b}}$ \\
\hline Omega 6 & $9.23 \pm 0.02^{\mathrm{d}}$ & $7.89 \pm 0^{\mathrm{c}}$ & $7.66 \pm 0^{\mathrm{a}}$ & $7.88 \pm 0.01^{\mathrm{c}}$ & $7.79 \pm 0.01^{\mathrm{b}}$ \\
\hline Omega3/omega6 & $2.10 \pm 0.01^{\mathrm{a}}$ & $2.86 \pm 0.01^{\mathrm{c}}$ & $2.84 \pm 0.01^{\mathrm{c}}$ & $2.80 \pm 0.02^{\mathrm{b}}$ & $2.80 \pm 0.03^{\mathrm{b}}$ \\
\hline Omega 9 & $18.99 \pm 0.01^{\mathrm{a}}$ & $22.50 \pm 0.01^{\mathrm{b}}$ & $23.42 \pm 0.01^{\mathrm{e}}$ & $22.69 \pm 0.01^{\mathrm{c}}$ & $23.02 \pm 0.03^{\mathrm{d}}$ \\
\hline
\end{tabular}

¿SFA: Total satured fatty acid, $\sum$ MUFA: Total mono unsaturated fatty acid, $\sum$ PUFA: Total poly unsaturated fatty acid Values in the same row with different superscripts are significantly different $(\mathrm{p}<0.05)$.

control group $(\mathrm{p}<0.05)$. $\sum$ PUFA value was higher in the control group compared to those in limited feeding groups $(\mathrm{p}<0.05)$.

Studies have shown that starvation period has effect on the fatty acid compositions of the fish (Akpinar and Aksoylar, 1988; De Silva et al., 1997). In various studies, changes have been observed in $\sum$ SFA, $\sum$ MUFA and $\sum$ PUFA values during starvation periods and this was found associated especially with fish species, energy metabolism and ambient conditions and it was additionally reported that the intensity of fish feed deprivation is also an importnat factor (Jezierska et al., 1982; Ringo et al., 1990; De Silva et al., 1997; Enien et al., 1998; Baki et al., 2013). ¿SFA and $\sum$ MUFA values increased in limited feeding groups whereas $\sum$ PUFA value decreased (Fig. 3).

It was found that omega-3 fatty acid which is composed of the essential fatty acid alpha-linolenic acid increased in all groups during the study. Omega-3 value of the control group was higher than those of the limited feeding groups $(p<0.05)$. Unlike the omega-3 fatty acids, omega- 6 fatty acid which is composed of linoleic acid decreased in all groups at the end of the study. The difference between the control group and $5 \mathrm{~F} / 2 \mathrm{~S}$ groups in terms of omega- 6 fatty acid was not significant $(p>0.05)$, however the differences between other groups were significant $(p<0.05)$. Omega-3/omega-6 ratio which 


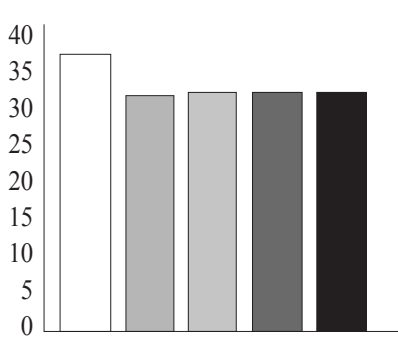

(a)

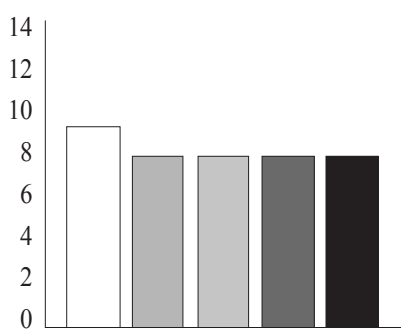

(e)

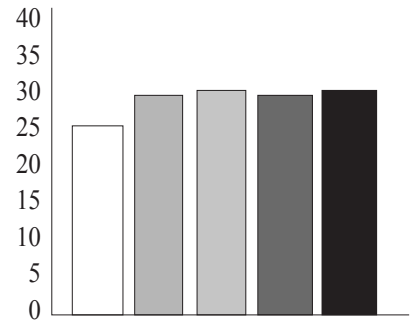

(b)

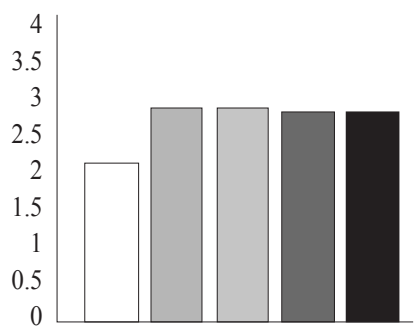

(f)

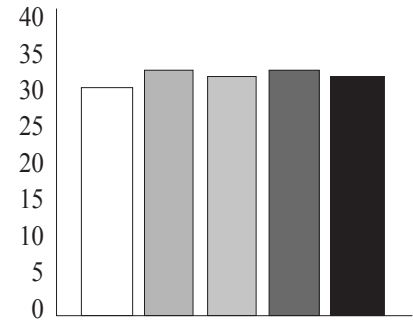

(c)

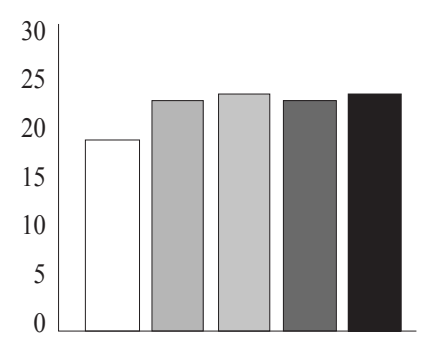

(g)

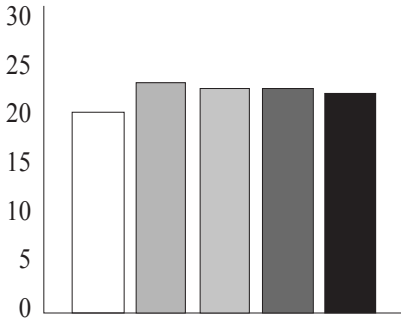

(d)

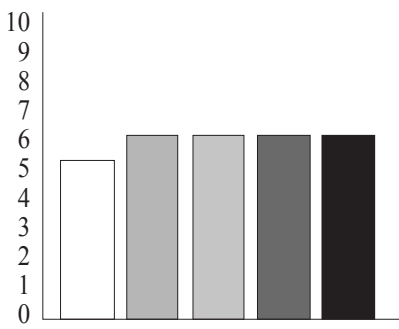

(h)

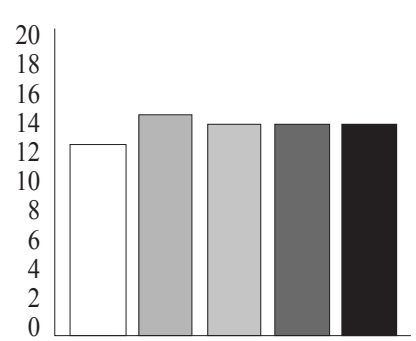

(i)

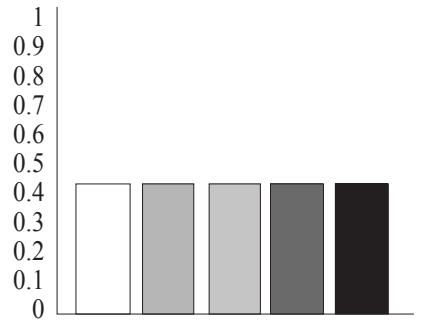

(j)

Fig. 3. Fatty acid levels in different experimental groups of European seabass. (a): $\sum$ SFA, (b): $\sum$ MUFA, (c): $\sum$ PUFA, (d): Omega-3, (e): Omega-6, (f): Omega-9, (g): Omega-3/Omega-6, (h): EPA, (i): DHA, (j): EPA/DHA

indicates an important quality parameter of the fish meat was $2.10 \pm 0.01 \%$ and it increased in all groups at the end of the experimental feeding. Similar values were obtained for limited feeding groups as well as for control group. Omega-9 value was $18.99 \pm 0.01 \%$ at the beginning of the study and it increased in all groups at the end of the study and the differences between the groups were significant $(\mathrm{p}<0.05)$.

EPA value was $5.19 \pm 0.01 \%$ initially which increased in all groups at the end of the study and the lowest value was recorded in $4 \mathrm{~F} / 3 \mathrm{~S}$ group $(\mathrm{p}<0.05)$. DHA value was $12.31 \pm 0.09 \%$ at the beginning of the study which increased in all groups on termination of the study. DHA value in the control group was higher compared to those of limited feeding groups $(\mathrm{p}<0.05)$.

Results of the correlation analysis performed between starvation periods and SFA, MUFA, PUFA, EPA, DHA, omega-3, omega-6 and omega-3/omega-6 ratio, showed that SFA and MUFA values increased with starvation period whereas DHA, PUFA, EPA, omega-3 and omega-3/omega-6 values decreased.
There was no correlation between starvation period and PUFA and omega-3 values $(r=0.11 ; r=0.13)$ whereas there was a strong correlation between omega-3/ omega-6 and starvation period $(\mathrm{r}=0.94)$. De Silva et al. (1997) reported that omega-3/omega-6 ratio increased during starvation period with DHA values in direct proportion to starvation period. The cells increased DHA levels in order to protect themselves as DHA is a main component of biological membranes (Tidwell et al., 1992).

The advantages of limited feeding in fish have been reported as the increase in growth and feed conversion ratio (Zhu et al., 2001; 2004). It was reported that fish exhibited a more rapid growth following starvation period and limited feeding protocols can be adopted in commercial aquaculture for achieving best growth values and feed conversion ratios (Zhu et al., 2001; Eroldogan et al., 2006; Gao et al., 2015).

In the present study, the effects of limited feeding on the growth, biochemical and fatty acid compositions in juvenile seabass were investigated. At the end of the 
study, it was observed that 1 day starvation per week had a positive effect on the growth parameters in juvenile seabass had no negative effects on the biochemical composition and had a negative effect on fatty acid composition. However, it was detected that two days and longer starvation periods per week, had more negative impact on the growth, biochemical and fatty acid compositions in juvenile seabass. Therefore, it was concluded that limited feeding applications in aquaculture should be carried out during periods when the growth is slower and the protein/ energy requirements are lower rather than during juvenile periods when the fish grow rapidly which require high protein/energy.

\section{References}

Adakli, A. and Tasbozan, O. 2015. The effects of different cycles of starvation and refeeding on growth and body composition on European seabass (Dicentrarchus labrax). Turk, J. Fish, Aquat. Sci., 15: 425-433. doi: 10.4194/1303-2712-v15 228.

Akpinar, M. A. and Aksoylar, M. Y. 1988. Effects of temperature, Dietary fatty acids and starvation on the fatty acids composition of Garra rufa Heckel, 1843. Doga. Tu. Biol. 12(1): $1-8$.

AOAC 2000. Official methods of analysis. Association of Official Analytical Chemists, Gaithersburg, M. D.

Baki, B., Kaya, D. and Ozturk R. 2013. Effects of periodic starvation on biochemical compositions of rainbow trout (Oncorhynchus mykiss, Walbaum, 1792). BIBAD, 6(1): 49-53.

Comoglio, L., Goldsmit, J. and Amin, O. 2008. Starvation effects on physiological parameters and biochemical composition of the hepatopancreas of the southern king crab Lithodes santolla (Molina, 1782). Revista de Biología Marinay Oceanografia, 43(2): 345-353.

Cui, Z. H., Wang, Y. and Qin, J. G. 2006. Compensatory growth of group-held gibel carp, Carassius auratus gibelio (Bloch), following feed deprivation. Aquac. Res., 37: 313-318. doi:10.1111/j.1365-2109.2005.01418.x.

De Silva, S. S., Gunasekera, R. M. and Austin, C. M. 1997. Changes in the fatty acid profiles of hybrid red tilapia, Oreochromis mossambicus X Oreochromis niloticus, subjected to short-term starvation and a comparison with changes in seawater raised fish. Aquaculture, 153: 273-290.

Echevarria, G., Martinez-Bebia, M. and Zamora, S. 1997. Evolution of biometric indices and plasma metabolites during prolonged starvation in European seabass (Dicentrarchus labrax, L.). Comp. Biochem. Physiol., 1118 A(1): 111-123.

Einen, O., Waagan, B. and Thomassen, M. S. 1998. Starvation prior to slaughter in Atlantic salmon (Salmo salar) 1. Effects on weight loss, body shape, slaughter-and filletyield, proximate and fatty acid composition. Aquaculture, 166: 85-104.
Eroldogan, O. T., Kumlu, M., Kırıs, G. A. and Sezer, B. 2006. Compensatory growth response of Sparus aurata following different starvation and refeeding protocols. Aquac Nutr., 12: 203-210. doi: 10.1111/j.1365-2095.2006.00402.x.

Eroldogan, O. T., Tasbozan, O. and Tabakoglu, S. 2008. Effects of restricted feeding regimes on growth and feed utilisation of juvenile gilthead seabream, Sparus aurata. J. World Aquac. Soc., 39(2): 267-274.

Firestone, D. and Horwitz, W. 1979. IUPAC gas chromatographic method for determination of fatty acid composition: collaborative study. J. As. Anal. Chem., 62: 709-721.

Gao, Y., Wang, Z., Hur, J. W. and Lee, J. Y. 2015. Body composition and compensatory growth in Nile tilapia Oreochromis niloticus under different feeding intervals. Chinese J. Oceanogr Limnol., 33(4): 945-956.

Guderley, H., Lapointe, D., Bedard, M. and Dutil, J. D. 2003. Metabolic priorities during starvation: enzyme sparing in liver and white muscle of Atlantic cod, Gadus morhua L. Comp. Biochem. Physiol., 2A: 347-356.

Halder, P. and Ali, H. 2015. Temporal changes in body composition of striped catfish (Pangasius hypophthalmus, Sauvage, 1878) during starvation. Int. J. Fish. Aquat. Stud., 3(2): 132-135.

Hossu, B., Korkut, A. Y. and Firat Kop, A. 2005. Balık Besleme ve Yem Teknolojisi 1.EgeUniversitesiYayınlarl, Su Urunleri Fakultesi Yayın, No: 50, Ders Kitabı Dizini, No: 19. Izmir.

Jezierska, B., Hazel, J. R. and Gerking, S. D. 1982. Lipid mobilisation during starvation in the rainbow trout, Salmo gairdneri, Richardson, with attention to fatty acids. J. Fish Biol., 21: 681-692.

Jobling, M. and Johansen, S. J. S. 1999. The lipostat, hyperphagia and catch-up growth. Aquac. Res., 30: 473-478. doi:10. 1046/j.1365-2109.1999.00358.x.

Jobling, M. 2010. Are compensatory growth and catch-up growth two sides of the same coin? Aquac. Int., 18: 501-510. doi: 10.1007/s10499-009-9260-8.

McCue, M. D. 2010. Starvation physiology: Reviewing the different strategies animals use to survive a common challenge. Comp. Biochem. Physiol., Part A, 156: 1-18.

Pastoureaud, A. 1991. Influence of starvation at low temperatures on utilisation of energy reserves, appetite recovery and growth character in seabass, Dicentrarchus labrax. Aquaculture, 99: 167-178.

Peres, H., Santos, S. and Oliva-Teles, A. 2011. Lack of compensatory growth response in gilthead seabream (Sparus aurata) juveniles following starvation and subsequent refeeding. Aquaculture, 318: 384-388. doi:10. 1016/j.aquaculture.2011.06.010.

Perez-Jimenez, A., Guedes, M. J., Morales, A. E. and OlivaTeres, A. 2007. Metabolic responses to short starvation and refeeding in Dicentrarchus labrax. Effect of dietary composition. Aquaculture, 265: 325-335. 
Ringo, E., Andreassen, T. V. and Burkow, I. C. 1990. Effects of starvation on the lipid composition in muscle tissue and liver of hatchery-reared Arctic charr, Salvelinus alpinus (L), from lake Takvatn, Fisk Dir Skr Ser Erncering, $3(2): 13-20$

Sevgili, H. 2007. Effects of different feeding restriction methods on quantitative and qualitative performance criterions in rainbow trout (Oncorhynchus mykiss). Ph. D. Thesis, Ege Universty, $185 \mathrm{pp}$.

Simkins, D. G. 2002. Responses of body condition and composition of juvenile rainbow trout to fasting, activity and water temperature. Ph. D. Thesis, Laramie, Wyoming.

Skalli, A. and Robın, J. H. 2004. Requirement of n-3 long chain polyunsaturated fatty acids for European seabass (Dicentrarchus labrax) juveniles: growth and fatty acid composition. Aquaculture, 240: 399-415. doi:10.1016/j. aquaculture.2004.06.036.

Takagi, Y. 2001. Effects of starvation and subsequent refeeding on formation and resorption of acellular bone in tilapia, Oreochromis niloticus. Zool. Scl., 18: 623-629. doi: http:// dx.doi.org/10.2108/zsj.18.623.

Tidwell, J. H., Webster, C. D. and Clarck, J. A. 1992. Effect of feeding, starvation and refeeding on the fatty acid composition of channel catfish Ictalurus punctatus tissues. Comp. Biochem. Physiol., 103A(2): 365-368.
Turkmen, S., Eroldogan, O. T., Yilmaz, H. A., Olçulu, A., KirisInan, G. A., Ercen, Z. and Tekelioglu, N. 2011. Compensatory growth response of European seabass (Dicentrarchus labrax L.) under cycled starvation and restricted feeding rate. Aquac. Res., p. 1-8. doi:10.1111/ j.1365-2109.2011.02970.x.

Wang, Y., Cui, Y., Yang, Y. X. and Cai, F. S. 2000. Compensatory growth in hybrid tilapia, Oreochromis mossambicus $x$ O. niloticus, reared in seawater. Aquaculture, 189: 101-108. doi: 10.1016/s0044-8486(00)00353-7.

Wu, G., Saoud, I. P., Miller, C. and Davis, D. A. 2004. The effect of feeding regimen on mixed-size pond-grown Channel catfish, Ictalurus punctatus, J. Appl. Aquac., 15: 115-125. doi: $10.1300 / J 028 v 15 n 03 \_09$.

Zhu, X., Cui, Y., Ali, M. and Wootton, R. J. 2001. Comparison of compensatory growth responses of juvenile three-spined stickleback and minnow following similar food deprivation protocols. J. Fish Biol., 58: 1149-1165. doi:10.1006/jfbi. 2000.1521.

Zhu, X., Xie, S., Zou, Z., Lei, W., Cui, Y., Yang, Y. and Wootton, R. J. 2004. Compensatory growth and food consumption in gibel carp, Carassius auratus gibelio and Chinese long snout catfish, Leiocassis longrostris, experiencing cycles of feed deprivation and re-feeding. Aquaculture, 241: 235-247. doi: 10.1016/j.aquaculture.2004.07.027. 